\title{
Control of Inclusion Composition in Calcium Treated Aluminum Killed Steels
}

\author{
Dongwei ZHAO, ${ }^{11}$ Haibo $\mathrm{LI}^{1)}{ }^{1)}$ Yang $\mathrm{CUI}^{1)}$ and Jian YANG ${ }^{21}$ \\ 1) Shougang Research Institute of Technology, No. 69, Yangzhuang Road, Shijingshan District, Beijing, 100041 China. \\ 2) Technical Quality Department of Qian'an Iron \& Steel CO., LTD, Yang DianZi Town Riverside Village, Qian'an, 064404 China.
}

(Received on March 1, 2016; accepted on April 7, 2016)

\begin{abstract}
Inclusions in slab samples with various total calcium, oxygen and sulfur content were investigated in low carbon aluminum killed steel (LCAK steel) with low sulfur content based on industrial experiments and the relationship between steel and inclusions was studied by analyzing inclusions characteristic being detected by SEM-EDS. It is found that T.Ca/T.O could better replace dissolved Ca to evaluate the extent of modification of alumina inclusions by $\mathrm{Ca}$. Inclusions changed from $\mathrm{Al}_{2} \mathrm{O}_{3}$ based inclusions to $\mathrm{Al}_{2} \mathrm{O}_{3}-\mathrm{CaS}$ inclusions and finally to $\mathrm{CaO}-\mathrm{CaS}$ inclusions with the increase of T.Ca/T.O in steel for slab samples and $\mathrm{MgO}$ and $\mathrm{Al}_{2} \mathrm{O}_{3}$ content in inclusions almost linearly decreased with T.Ca/T.O in steel. Increasing T.Ca/S in steel could improve the modification extent of alumina by Ca further increased CaS content of inclusions for slab samples with $\mathrm{Al}_{2} \mathrm{O}_{3}-\mathrm{CaS}$ inclusions. In addition, the formation mechanism of inclusions including $\mathrm{Al}_{2} \mathrm{O}_{3}$ based inclusions, $\mathrm{Al}_{2} \mathrm{O}_{3}-\mathrm{CaS}$ inclusions and $\mathrm{CaO}-\mathrm{CaS}$ inclusions was discussed.
\end{abstract}

KEY WORDS: inclusions; composition; calcium treatment; aluminum killed steel.

\section{Introduction}

For low carbon aluminum killed steel, lots of $\mathrm{Al}_{2} \mathrm{O}_{3}$ inclusions are generated after aluminum alloy being fed into molten steel with a small amount of dissolved oxygen and they are often considered to be harmful to castability and final product quality. Calcium treatment, by wire feeding, is commonly used to modify solid alumina inclusions to form various typed calcium aluminates. Excess or insufficient calcium addition can produce solid $\mathrm{CaS}$ or low modified calcium aluminates with higher melting, which are harmful. In actual production, it is almost impossible to modify all the alumina inclusions to fully liquid ones. Thus, the composition of inclusions, such as $\mathrm{MgO}, \mathrm{Al}_{2} \mathrm{O}_{3}, \mathrm{CaO}$ and $\mathrm{CaS}$, should be well controlled in order to get desired properties of steel.

To better control the composition of inclusions, lots of work has been done by previous researchers based on laboratory experiment or thermodynamic calculation. Yang et $a l .{ }^{1,2)}$ studied the effect of calcium addition on the variation of inclusion composition in low carbon Al-killed steel with induction vacuum furnace and found that the $\mathrm{Al}_{2} \mathrm{O}_{3}$ content in inclusions linearly decreased by increasing T.Ca/T.O in steel and it disappeared when T.Ca/T.O exceeded 3 and $\mathrm{CaS} / \mathrm{CaO}$ of the inclusions linearly increased by increasing $\mathrm{S} / \mathrm{T}$.O in steel. Numata et al. ${ }^{3,4)}$ investigated the calcium consumption and calcium addition pattern on the change of inclusion composition. They found $\mathrm{CaO}-\mathrm{CaS}$ typed inclusions in steel with $0.0015 \%$ sulfur content after calcium addition. Choudhary et al. ${ }^{5)}$ developed a thermodynamic model for predicting the formation of oxide-sulfide duplex inclusions in Al-killed steel and found that increasing $\mathrm{S}$ content in steel made complete modification of alumina inclusions into liquid calcium aluminate become difficult. Holappa et al. ${ }^{6}$ ) studied the formation and transformation of liquid and solid inclusions containing oxidic and sulphidic components by thermodynamic calculations and found increasing dissolved oxygen content and decreasing sulfur content in steel made the modification of alumina by $\mathrm{Ca}$ become easier. Suito et al. $^{7)}$ calculated the relation among the compositions of inclusion, various typed steel and top slag at $1823 \mathrm{~K}$ based on thermodynamic calculation and found that the contents of $\mathrm{Si}, \mathrm{O}$, and $\mathrm{Ca}$ in an ultra-low carbon steel were determined as a function of top slag composition. It is worth noting that laboratory experiments only represent for the results of laboratory condition, which often exists difference with the ones of actual conditions, and thermodynamic model also only represent for result of the equilibrium condition, not actual condition.

In present work, inclusions in slab samples with various compositions of molten steel were investigated in Al-killed steel with low sulfur content based on industrial trails. Contents of $\mathrm{MgO}, \mathrm{Al}_{2} \mathrm{O}_{3}, \mathrm{CaO}$ and $\mathrm{CaS}$ are easily achieved by SEM-EDS and the relation between the compositions of inclusions and molten steel was studied and the formation mechanism of inclusions including $\mathrm{Al}_{2} \mathrm{O}_{3}$ based inclusions, $\mathrm{Al}_{2} \mathrm{O}_{3}-\mathrm{CaS}$ inclusions and $\mathrm{CaO}-\mathrm{CaS}$ inclusions was discussed.

\footnotetext{
* Corresponding author: E-mail: idongwei@126.com

DOI: http://dx.doi.org/10.2355/isijinternational.ISIJINT-2016-123
} 


\section{Experimental Methods}

38 heats industrial trials were carried out in Qian'an Steel Corporation with two kinds of desulfurization method during LF refining to investigate the relation between the compositions of inclusions and molten steel.

The process was as follow, hot metal pretreatment $\rightarrow$ basic oxygen furnace $(\mathrm{BOF}) \rightarrow$ ladle furnace $(\mathrm{LF}) \rightarrow \mathrm{RH} \rightarrow$ continuous casting $(\mathrm{CC}) \rightarrow$ hot rolling. During the experiment, the steel making process was carried out in a $210 \mathrm{t}$ basic oxygen furnace. After tapping into a ladle, the steel was deslagged, and then a new synthetic slag was added, as well as deoxidizer and the remaining alloys. When the molten steel had the right temperature and chemical composition, the ladle was transferred to the ladle furnace station and alloy was added to deoxidize and meet the composition requirement. During LF refining, the first 28 heats named No. 1 to 28 were desulfurized with the higher basic and stronger reducing refining slag and the remained 8 heats named No. 29 to 36 with relatively lower basicity to achieve higher sulfur content. After LF refining, the ladle was transferred to $\mathrm{RH}$ for degassing and removing non-metallic inclusions. After 30 mins RH treatment, various amounts of $\mathrm{Ca}$ wire were fed into liquid steel with a speed of $14.4 \mathrm{~kg} / \mathrm{min}$ and then soft bottom blowing by argon gas was carried out with the flow rate of $10 \mathrm{Nl} / \mathrm{min}$ for $10 \mathrm{mins}$. Finally, the slabs with thickness of $230 \mathrm{~mm}$ were produced by continuous casting and hot rolled into plate with thickness of $20 \mathrm{~mm}$.

Slag samples were collected from ladles just at the end of $\mathrm{RH}$ refining and slab samples $(25 \mathrm{~mm} \times 25 \mathrm{~mm} \times 20$ $\mathrm{mm}$ thickness), $50 \mathrm{~mm}$ from the intrados of slab and plate samples $(20 \mathrm{~mm} \times 20 \mathrm{~mm} \times 20 \mathrm{~mm}$ thickness $)$ were also cut from slabs. These metallographic samples were polished by $\mathrm{SiC}$ paper and diamond suspensions to characterize the inclusions. The chemical compositions of the steel samples and slag samples were analyzed with chemical methods. Inclusions were observed by scanning electron microscopy (SEM) and ASPEX ${ }^{\circledR}$, whose compositions were evaluated by energy dispersive spectrometry (EDS).

\section{Expermental Results}

\subsection{Compositions of Slab and Slag}

The compositions of refining slags at the end of $\mathrm{RH}$ refining are listed in Table 1. By adding synthetic slag and aluminum to the slag, the content of TFe (total $\mathrm{Fe}$ ) in slag was decreased to $<0.8 \%$ for No. 1 to 28 and $<1.5 \%$ for No. 29 to 36 respectively. At the same time, the slag basicity was increased to 6-9 for No. 1 to 28 and 4-7 for No. 29 to 36 respectively, which was benefit for deep desulfurization of the molten steel and ensured the stable subsequent calcium treatment. The composition of slab samples is listed in Table 2. Contents of sulfur (S), total aluminum (Alt), total

Table 1. The composition of refining slag.

\begin{tabular}{ccccccc}
\hline process & $\begin{array}{c}\text { sample } \\
\text { number }\end{array}$ & $\begin{array}{c}\mathrm{CaO} \\
\text { mass\% }\end{array}$ & $\begin{array}{c}\mathrm{SiO}_{2} \\
\text { mass\% }\end{array}$ & $\begin{array}{c}\mathrm{Al}_{2} \mathrm{O}_{3} \\
\text { mass\% }\end{array}$ & $\begin{array}{c}\mathrm{TFe} \\
\text { mass\% }\end{array}$ & Basicity \\
\hline 1 & $1-28$ & $50-56$ & $6-10$ & $21-30$ & $<0.8$ & $6-9$ \\
2 & $29-36$ & $40-46$ & $7-12$ & $22-31$ & $<1.5$ & $4-7$ \\
\hline
\end{tabular}

calcium (T.Ca) and total oxygen (T.O) are in the range of $0.0006-0.0060 \%, 0.0280-0.0422 \%, 0.0002-0.0030 \%$ and $0.0009-0.0023 \%$.

\subsection{Characterization of Inclusions}

The element mappings of four kinds of typical inclusions including $\mathrm{Al}_{2} \mathrm{O}_{3}$ based inclusion, $\mathrm{CaO}-\mathrm{Al}_{2} \mathrm{O}_{3}$ inclusion, $\mathrm{Al}_{2} \mathrm{O}_{3}-\mathrm{CaS}$ inclusion and $\mathrm{CaO}-\mathrm{CaS}$ inclusion detected

Table 2. The composition of 38 heats in slab samples, mass $\%$.

\begin{tabular}{|c|c|c|c|c|}
\hline No. & $\mathrm{S}$ & Alt & T.Ca & T.O \\
\hline 1 & 0.0011 & 0.0281 & 0.0022 & 0.0014 \\
\hline 2 & 0.0012 & 0.0301 & 0.0024 & 0.0013 \\
\hline 3 & 0.0009 & 0.0413 & 0.0015 & 0.0008 \\
\hline 4 & 0.0009 & 0.0420 & 0.0016 & 0.0011 \\
\hline 5 & 0.0010 & 0.0372 & 0.0015 & 0.0009 \\
\hline 6 & 0.0011 & 0.0354 & 0.0015 & 0.0010 \\
\hline 7 & 0.0010 & 0.0358 & 0.0017 & 0.0012 \\
\hline 8 & 0.0011 & 0.0365 & 0.0017 & 0.0008 \\
\hline 9 & 0.0007 & 0.0403 & 0.0018 & 0.0009 \\
\hline 10 & 0.0008 & 0.0418 & 0.0018 & 0.0010 \\
\hline 11 & 0.0010 & 0.0319 & 0.0012 & 0.0013 \\
\hline 12 & 0.0010 & 0.0304 & 0.0012 & 0.0014 \\
\hline 13 & 0.0009 & 0.0381 & 0.0009 & 0.0008 \\
\hline 14 & 0.0007 & 0.0366 & 0.0005 & 0.0007 \\
\hline 15 & 0.0008 & 0.0357 & 0.0013 & 0.0009 \\
\hline 16 & 0.0008 & 0.0346 & 0.0011 & 0.0012 \\
\hline 17 & 0.0012 & 0.0308 & 0.0005 & 0.0014 \\
\hline 18 & 0.0011 & 0.0290 & 0.0006 & 0.0013 \\
\hline 19 & 0.0012 & 0.0335 & 0.0008 & 0.0010 \\
\hline 20 & 0.0012 & 0.0326 & 0.0008 & 0.0009 \\
\hline 21 & 0.0008 & 0.0367 & 0.0002 & 0.0013 \\
\hline 22 & 0.0009 & 0.0350 & 0.0011 & 0.0016 \\
\hline 23 & 0.0006 & 0.0364 & 0.0013 & 0.0011 \\
\hline 24 & 0.0007 & 0.0389 & 0.0020 & 0.0015 \\
\hline 25 & 0.0007 & 0.0305 & 0.0015 & 0.0010 \\
\hline 26 & 0.0009 & 0.0326 & 0.0008 & 0.0011 \\
\hline 27 & 0.0009 & 0.0292 & 0.0003 & 0.0009 \\
\hline 28 & 0.0009 & 0.0344 & 0.0007 & 0.0012 \\
\hline 29 & 0.0060 & 0.0292 & 0.0023 & 0.0024 \\
\hline 30 & 0.0030 & 0.0354 & 0.0021 & 0.0020 \\
\hline 31 & 0.0027 & 0.0393 & 0.0028 & 0.0023 \\
\hline 32 & 0.0016 & 0.0427 & 0.0014 & 0.0012 \\
\hline 33 & 0.0040 & 0.0289 & 0.0002 & 0.0015 \\
\hline 34 & 0.0030 & 0.0291 & 0.0022 & 0.0016 \\
\hline 35 & 0.0020 & 0.0400 & 0.0023 & 0.0019 \\
\hline 36 & 0.0021 & 0.0312 & 0.0030 & 0.0018 \\
\hline
\end{tabular}

Total oxygen was analyzed by the inert gas fusion impulse infrared absorption spectroscopy method. Other chemical compositions were obtained by ICP-AES. 
in slab samples are shown in Fig. 1. Figure 1(a) shows a typical $\mathrm{Al}_{2} \mathrm{O}_{3}$ based inclusion (or low modified $\mathrm{CaO}$ $\mathrm{Al}_{2} \mathrm{O}_{3}$ inclusion), where $\mathrm{Al}$ and $\mathrm{O}$ distributed almost over the whole inclusion and some of them contained a small amount of calcium. This one could be detected in samples 17-18, 21, 27 and 33. Figures 1(b) and 1(c) show two types of $\mathrm{Al}_{2} \mathrm{O}_{3}-\mathrm{CaS}$ complex inclusion, one type of inclusion like inclusion (b) existed a crescent shaped $\mathrm{CaS}$ layer surrounding calcium aluminates where $\mathrm{Al}$ and $\mathrm{Ca}$ uniformly distributed over the whole inclusion and the other type of inclusion like inclusion (c) with an oval CaS layer seemed to be composed of two particles and their formation mechanism has been reported by previous article. ${ }^{8)}$ They could be detected in samples No. 11-16, 19-20, 23-24, 26, 28-32 and 34-36. Figure 1(d) shows a typical better modified calcium aluminate, where $\mathrm{Ca}$ and $\mathrm{Al}$ distributed almost over the whole inclusions and it could be detected in sample 22. Figure 1(e) shows a typical $\mathrm{CaO}-\mathrm{CaS}$ inclusion, where $\mathrm{Ca}$, $\mathrm{S}$ and $\mathrm{O}$ distributed almost over the whole inclusion and nearly no aluminum was detected.

\subsection{Composition of Inclusions}

A large number of inclusions in slab samples were observed by SEM-EDS and ASPEX ${ }^{\circledR}$ and the results from EDS show that the component of inclusions mainly contained $\mathrm{CaO}, \mathrm{Al}_{2} \mathrm{O}_{3}, \mathrm{CaS}$ and $\mathrm{MgO}$. The average composition of inclusions and number density of all the slab samples are given and shown in Table 3, where CC, CA, A and AC mean $\mathrm{CaO}-\mathrm{CaS}$ inclusion, $\mathrm{CaO}-\mathrm{Al}_{2} \mathrm{O}_{3}$ inclusion, alumina and $\mathrm{Al}_{2} \mathrm{O}_{3}-\mathrm{CaS}$ inclusion respectively. One thing to note is that all inclusions compositions are normalized to unity and other components excluding $\mathrm{MgO}, \mathrm{Al}_{2} \mathrm{O}_{3}, \mathrm{CaO}$ and $\mathrm{CaS}$ are ignored, which is not of any interest to study alumina inclusions modification.

To better show the composition distribution of inclusions, inclusions with all sizes were projected in $\mathrm{Al}_{2} \mathrm{O}_{3}-\mathrm{MgO}-\mathrm{CaO}$ or $\mathrm{Al}_{2} \mathrm{O}_{3}-\mathrm{CaS}-\mathrm{CaO}$ ternary phase diagram mainly based on inclusions components. Three typical types of inclusions from samples No. 1, 13 and 27 were chosen and their compositions were projected in ternary phase diagram shown in Fig. 2, where each solid circle represents for an individual inclusion and the solid line for liquidus line in $1873 \mathrm{~K}$ $\left(1600^{\circ} \mathrm{C}\right)$. As can be seen in Fig. 2(a), almost all the points are close to $\mathrm{CaO}-\mathrm{CaS}$ line in $\mathrm{Al}_{2} \mathrm{O}_{3}-\mathrm{CaS}-\mathrm{CaO}$ ternary phase diagram and the element mapping of a typical $\mathrm{CaO}-\mathrm{CaS}$ inclusion is shown in Fig. 1(e). In contrast, the points shown in Fig. 2(b) are mainly close to $\mathrm{Al}_{2} \mathrm{O}_{3}-\mathrm{CaS}$ line and part of them contains less $\mathrm{CaO}$ content. The elemental mappings of two types of $\mathrm{Al}_{2} \mathrm{O}_{3}-\mathrm{CaS}$ inclusions are shown in Figs. 1(b) and 1(c). Besides, the points shown in Fig. 2(c) are close to $\mathrm{Al}_{2} \mathrm{O}_{3}$ corner, which indicates $\mathrm{Al}_{2} \mathrm{O}_{3}$ based inclusion is not almost modified by $\mathrm{Ca}$ and part of them are modified into $\mathrm{MgO}-\mathrm{Al}_{2} \mathrm{O}_{3}$ inclusions.

\section{Discussion}

\subsection{Evaluation of Dissolved Ca in Molten Steel}

To evaluate the extent of modification of alumina inclusion, $\mathrm{Ca}$ content is an important parameter, which includes dissolved $\mathrm{Ca}$ in molten steel and undissolved $\mathrm{Ca}$ in $\mathrm{CaS}$ and $\mathrm{CaO}$, as expressed by Eq. (1). In fact, it is that the dissolved Ca plays an important role in alumina modification. However, dissolved $\mathrm{Ca}$ is very difficult to be directly measured accurately. To better evaluate the extent of modification of alumina inclusion by dissolved $\mathrm{Ca}$ in steel, the mass ratio of T.Ca/T.O was introduced. The T.O in Table 2 includes dissolved oxygen in steel and undissolved oxygen in oxide inclusions, as expressed by Eq. (2). By combining Eqs. (1) and (2), the mass ratio of T.Ca/T.O can be described as a function of $\mathrm{Ca}_{\text {dissolved }} / \mathrm{O}_{\text {oxide }}, \mathrm{Ca}_{\text {oxide }} / \mathrm{O}_{\text {oxide }}, \mathrm{Ca} \mathrm{CaS}_{\mathrm{CaS}} / \mathrm{O}_{\text {oxide }}$ and $\mathrm{O}_{\text {dissolved }} / \mathrm{T}$.O, as expressed by Eq. (3), where $\mathrm{Ca}_{\text {dissolved }} /$ $\mathrm{O}_{\text {oxide }}$ means the extent of modification of oxide inclusion
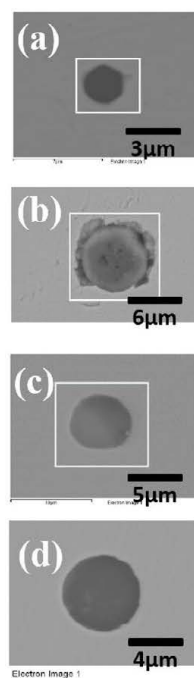

(e)

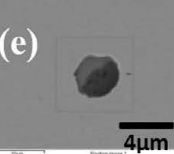

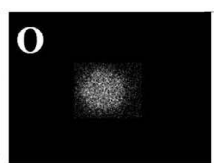
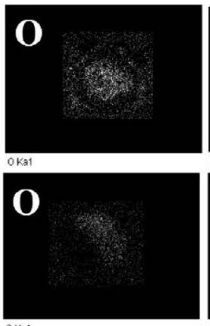

$\mathbf{0}$
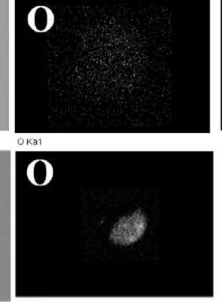
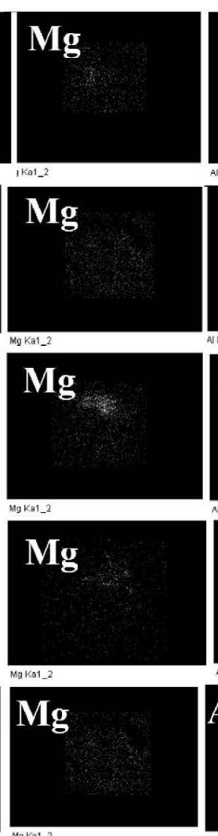
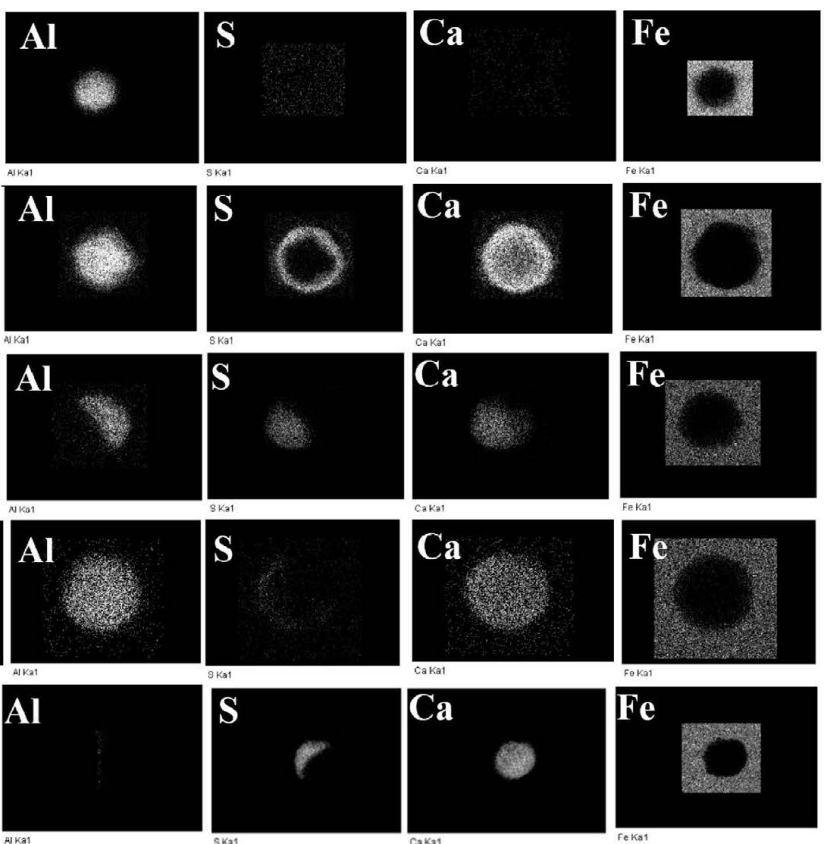

Fig. 1. Element mappings of typical inclusions detected in slab samples (a) a typical $\mathrm{Al}_{2} \mathrm{O}_{3}$ based inclusion; (b) a typical $\mathrm{Al}_{2} \mathrm{O}_{3}-\mathrm{CaS}$ inclusion with a crescent shaped $\mathrm{CaS}$ layer; (c) a typical $\mathrm{Al}_{2} \mathrm{O}_{3}-\mathrm{CaS}$ inclusion with a oval shaped $\mathrm{CaS}$ layer; (d) a typical better modified calcium aluminate; (e) a typical $\mathrm{CaO}-\mathrm{CaS}$ inclusion. 
ISIJ International, Vol. 56 (2016), No. 7

Table 3. The composition of inclusions from 38 heats in slab samples.

\begin{tabular}{|c|c|c|c|c|c|c|c|c|c|c|c|c|c|}
\hline No. & $\begin{array}{l}\text { Inclusion } \\
\text { type }\end{array}$ & $\begin{array}{c}\mathrm{MgO} \\
\operatorname{mass} \%\end{array}$ & $\begin{array}{c}\mathrm{CaO} \\
\mathrm{mass} \%\end{array}$ & $\begin{array}{l}\mathrm{Al}_{2} \mathrm{O}_{3} \\
\text { mass \% }\end{array}$ & $\begin{array}{c}\mathrm{CaS} \\
\operatorname{mass} \%\end{array}$ & $\begin{array}{c}\text { Number } \\
\text { density } / \mathrm{mm}^{2}\end{array}$ & No. & $\begin{array}{l}\text { Inclusion } \\
\text { type }\end{array}$ & $\begin{array}{c}\mathrm{MgO} \\
\operatorname{mass} \%\end{array}$ & $\begin{array}{c}\mathrm{CaO} \\
\mathrm{mass} \%\end{array}$ & $\begin{array}{l}\mathrm{Al}_{2} \mathrm{O}_{3} \\
\text { mass } \%\end{array}$ & $\begin{array}{c}\mathrm{CaS} \\
\mathrm{mass} \%\end{array}$ & $\begin{array}{c}\text { Number } \\
\text { density } / \mathrm{mm}^{2}\end{array}$ \\
\hline 1 & $\mathrm{CC}$ & 2.9 & 43.8 & 7.6 & 45.7 & 12.7 & 19 & $\mathrm{AC}$ & 10.7 & 3.6 & 45.5 & 40.2 & 13.5 \\
\hline 2 & $\mathrm{CC}$ & 3.8 & 38.5 & 2.9 & 54.8 & 15.6 & 20 & $\mathrm{AC}$ & 10.7 & 1.8 & 44.6 & 42.9 & 10.2 \\
\hline 3 & $\mathrm{CC}$ & 3.8 & 20.2 & 3.8 & 72.1 & 10.9 & 21 & A & 20.0 & 2.4 & 75.2 & 2.4 & 10.0 \\
\hline 4 & $\mathrm{CC}$ & 2.0 & 44.1 & 5.9 & 48.0 & 13.6 & 22 & $\mathrm{CA}$ & 13.0 & 41.7 & 33.9 & 11.3 & 15.7 \\
\hline 5 & $\mathrm{CC}$ & 2.0 & 45.1 & 1.0 & 52.0 & 12.5 & 23 & $\mathrm{AC}$ & 11.5 & 17.7 & 24.8 & 46.0 & 12.8 \\
\hline 6 & $\mathrm{CC}$ & 3.8 & 21.2 & 2.9 & 72.1 & 12.4 & 24 & $\mathrm{AC}$ & 8.3 & 14.7 & 42.2 & 34.9 & 20.3 \\
\hline 7 & $\mathrm{CC}$ & 5.7 & 19.8 & 5.7 & 68.9 & 13.1 & 25 & $\mathrm{CC}$ & 2.9 & 44.7 & 1.9 & 50.5 & 10.8 \\
\hline 8 & $\mathrm{CC}$ & 3.8 & 12.5 & 10.6 & 73.1 & 11.8 & 26 & $\mathrm{AC}$ & 13.8 & 12.9 & 53.4 & 19.8 & 6.3 \\
\hline 9 & $\mathrm{CC}$ & 2.9 & 22.3 & 3.9 & 70.9 & 14.9 & 27 & A & 18.0 & 4.1 & 70.5 & 7.4 & 8.7 \\
\hline 10 & $\mathrm{CC}$ & 4.8 & 40.0 & 2.9 & 52.4 & 21.3 & 28 & $\mathrm{AC}$ & 21.9 & 10.2 & 50.8 & 17.2 & 14.5 \\
\hline 11 & $\mathrm{AC}$ & 10.7 & 17.9 & 46.4 & 25.0 & 13.9 & 29 & $\mathrm{AC}$ & 9.1 & 13.6 & 59.1 & 18.2 & 29.4 \\
\hline 12 & $\mathrm{AC}$ & 9.9 & 19.8 & 45.9 & 24.3 & 11.3 & 30 & $\mathrm{AC}$ & 13.8 & 12.1 & 56.9 & 17.2 & 30.1 \\
\hline 13 & $\mathrm{AC}$ & 11.5 & 1.8 & 46.0 & 40.7 & 15.0 & 31 & $\mathrm{AC}$ & 10.7 & 12.5 & 42.0 & 34.8 & 36.4 \\
\hline 14 & $\mathrm{AC}$ & 7.4 & 1.9 & 38.9 & 51.9 & 11.3 & 32 & $\mathrm{AC}$ & 5.7 & 17.9 & 49.1 & 27.4 & 9.9 \\
\hline 15 & $\mathrm{AC}$ & 8.3 & 8.3 & 46.8 & 36.7 & 9.1 & 33 & A & 16.0 & 1.7 & 80.7 & 1.7 & 12.3 \\
\hline 16 & $\mathrm{AC}$ & 11.5 & 2.7 & 46.9 & 38.9 & 4.4 & 34 & $\mathrm{AC}$ & 5.7 & 3.8 & 21.7 & 68.9 & 16.9 \\
\hline 17 & A & 6.5 & 4.7 & 72.9 & 15.9 & 13.8 & 35 & $\mathrm{AC}$ & 4.8 & 6.7 & 23.8 & 64.8 & 19.2 \\
\hline 18 & A & 9.1 & 10.9 & 68.2 & 11.8 & 20.5 & 36 & $\mathrm{AC}$ & 5.7 & 11.3 & 39.6 & 43.4 & 29.3 \\
\hline
\end{tabular}

The number density equals the number of all the inclusions divided by scanning area.
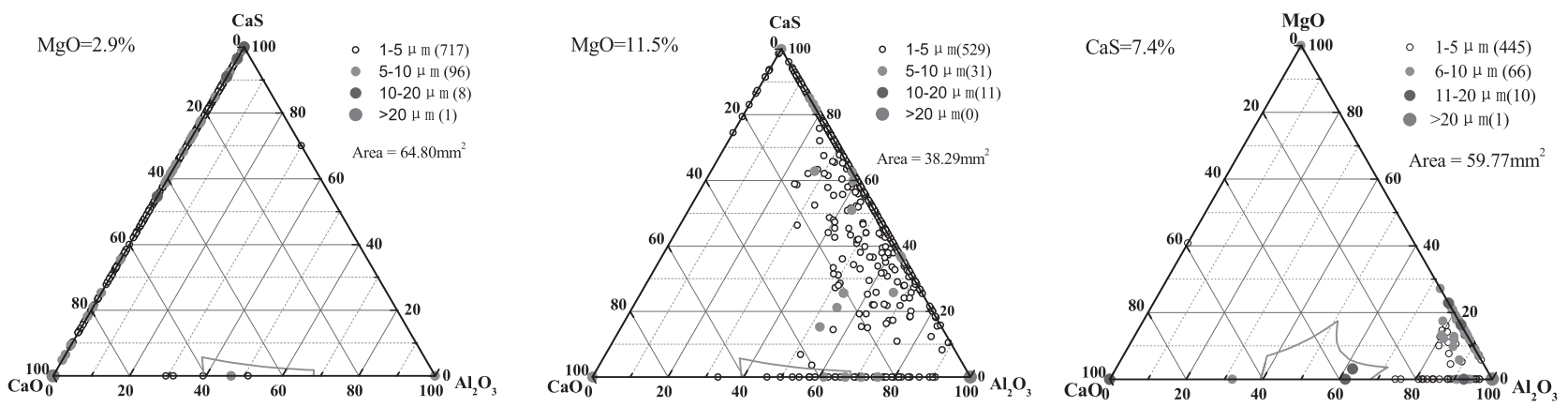

Fig. 2. The distribution of inclusions composition in $\mathrm{Al}_{2} \mathrm{O}_{3}-\mathrm{CaO}-\mathrm{CaS}$ or $\mathrm{Al}_{2} \mathrm{O}_{3}-\mathrm{CaO}-\mathrm{MgO}$ ternary phase diagram (a) $\mathrm{CaO}-\mathrm{CaS}$ inclusions from No. 1 slab sample; (b) $\mathrm{Al}_{2} \mathrm{O}_{3}-\mathrm{CaS}$ inclusions from No. 13 slab sample; (c) $\mathrm{Al}_{2} \mathrm{O}_{3}$ based inclusions from No. 27 slab sample.

by dissolved $\mathrm{Ca}$ in steel. $\mathrm{Ca}_{\text {oxide }} / \mathrm{O}_{\text {oxide }}$ means the mass ratio of calcium to oxygen in oxides and its value is shown in Table 4, which assumes that oxide inclusion in steel is one of three typed inclusions including CA6, CA or C12A7, where $\mathrm{C}$ and $\mathrm{A}$ mean $\mathrm{CaO}$ and $\mathrm{Al}_{2} \mathrm{O}_{3}$ respectively. $\mathrm{Ca}$ Cas/ $\mathrm{O}_{\text {oxide }}$ means the mass ratio of calcium of $\mathrm{CaS}$ to oxygen of oxide inclusion and is regarded as zero because $\mathrm{CaS}$ is very difficult to generate in molten steel in the case of low sulfur content according to the results reported by Refs. 9), 10). The dissolved oxygen $\left(\mathrm{O}_{\text {dissolved }}\right)$ in molten steel before calcium treatment is determined by the equilibrium between $\mathrm{Al}$ in the steel and $\mathrm{Al}_{2} \mathrm{O}_{3}$ in the inclusions, as expressed by Eqs. (4) and (5) and $\mathrm{O}_{\text {dissolved }}$ is given by Eq. (6), where the activity of $\mathrm{Al}_{2} \mathrm{O}_{3}$ has been reported by Ref. 8) and shown in Table 4.

$$
T . C a=C a_{\text {dissolved }}+C a_{O \text { xide }}+C a_{C a S}
$$

Table 4. The mass ratio of $\mathrm{Ca}_{\text {oxide }} / \mathrm{O}_{\text {oxide }}$ and activity of $\mathrm{Al}_{2} \mathrm{O}_{3}$ in various calcium aluminates.

\begin{tabular}{cccc}
\hline Oxide inclusion & CA6 & CA & C12A7 \\
\hline Mass ratio of $\mathrm{Ca}_{\text {oxide }} / \mathrm{O}_{\text {oxide }}$ & 0.1316 & 0.6250 & 0.9091 \\
Activity of $\mathrm{Al}_{2} \mathrm{O}_{3}$ in CxAy inclusion & 0.5102 & 0.2467 & 0.0536 \\
\hline
\end{tabular}

$$
T . O=O_{\text {dissolved }}+O_{O \text { xide }}
$$

$$
\begin{aligned}
\frac{T . C a}{T . O} & =\frac{C a_{\text {dissolved }}+C a_{\text {Oxide }}+C a_{\text {CaS }}}{O_{\text {dissolved }}+O_{\text {Oxide }}} \\
& =\left(\frac{C a_{\text {dissolved }}}{O_{\text {oxide }}}+\frac{C a_{\text {oxide }}}{O_{\text {oxide }}}+\frac{C a_{\text {CaS }}}{O_{\text {oxide }}}\right) \cdot\left(1-\frac{O_{\text {dissolved }}}{T . O}\right)
\end{aligned}
$$




$$
\begin{gathered}
2[A l]+3[O]=\mathrm{Al}_{2} \mathrm{O}_{3(s)} \ldots \ldots \ldots \ldots \ldots \ldots \ldots \ldots \ldots \ldots \ldots \ldots \ldots \ldots \ldots \\
\Delta G_{1}^{\theta}=-1225417+393.8 T \ldots \ldots \ldots \ldots \ldots \ldots \\
O_{\text {dissolved }}=\left(\exp \left(\frac{\Delta G_{1}^{\theta}}{R T}\right) \frac{a_{A l 2 O 3}}{f_{A l}^{2} f_{O}^{3}[\text { mass } \% A l]^{2}}\right)^{1 / 3} \ldots
\end{gathered}
$$

Based on the experimental results shown in Tables 1-4 and Eqs. (1)-(6), the relation between T.Ca/T.O and $\mathrm{Ca}_{\text {dissolved }} / \mathrm{O}_{\text {oxide }}$ with various calcium aluminates is shown in Fig. 3. As shown, $\mathrm{Ca}_{\text {dissolved }} / \mathrm{O}_{\text {oxide }}$ increases with the increase of T.Ca/T.O and their relationship is close to a nearly liner indicating that T.Ca/T.O can show the extent of modification of alumina inclusions by calcium. Besides, it is noticed that $\mathrm{Ca}_{\text {dissolved }} / \mathrm{O}_{\text {oxide }}$ of CA6 is higher than $\mathrm{Ca}_{\text {dissolved }} / \mathrm{O}_{\text {oxide }}$ of $\mathrm{C} 12 \mathrm{~A} 7$ in the case T.Ca/T.O is constant. The main reason is that dissolved $\mathrm{Ca}$ in molten steel is equal to T.Ca minus undissolved $\mathrm{Ca}$ in inclusions according to Eq. (3) while undissolved $\mathrm{Ca}$ of CA6 is less than that one of C12A7. Actually, dissolved $\mathrm{Ca}$ of Eq. (3) should be equal or greater than the equilibrium $\mathrm{Ca}$ between steel and inclusions. So $\mathrm{Ca}_{\text {dissolved }} / \mathrm{O}_{\text {oxide }}$ of inclusions indicates the ease or complexity of inclusions being modified by dissolved $\mathrm{Ca}$ in molten steel. That is to say, low modified calcium aluminates with higher $\mathrm{Ca}_{\text {dissolved }} / \mathrm{O}_{\text {oxide }}$ are easier to be modified into better calcium aluminates by dissolved $\mathrm{Ca}$ in molten steel.

\subsection{Effect of T.Ca/T.O on the MgO Content of Inclu- sions}

For Al-killed steel, there are two manners for $\mathrm{Al}_{2} \mathrm{O}_{3}$ inclusions modification during LF refining: the first route is followed by $\mathrm{Al}_{2} \mathrm{O}_{3} \rightarrow$ low modified calcium aluminates $\rightarrow$ liquid calcium aluminates and the other is as $\mathrm{Al}_{2} \mathrm{O}_{3} \rightarrow \mathrm{MgO}-\mathrm{Al}_{2} \mathrm{O}_{3}$ spinel $\rightarrow \mathrm{CaO}-\mathrm{MgO}-\mathrm{Al}_{2} \mathrm{O}_{3}$ multi-component inclusion. $\mathrm{MgO}-\mathrm{Al}_{2} \mathrm{O}_{3}$ spinel is generated before calcium treatment and transfers into $\mathrm{CaO}-\mathrm{Al}_{2} \mathrm{O}_{3}-\mathrm{MgO}$ after calcium wire being fed, which has been demonstrated by researchers ${ }^{10-12)}$ and the process can be described by Eq. (7).

$$
\begin{aligned}
& \mathrm{x}[\mathrm{Ca}]+(\mathrm{MgO})_{y} \cdot\left(\mathrm{Al}_{2} \mathrm{O}_{3}\right)_{z} \\
& =(\mathrm{MgO})_{y-x} \cdot(\mathrm{CaO})_{x} \cdot\left(\mathrm{Al}_{2} \mathrm{O}_{3}\right)_{z}+x[\mathrm{Mg}]
\end{aligned}
$$

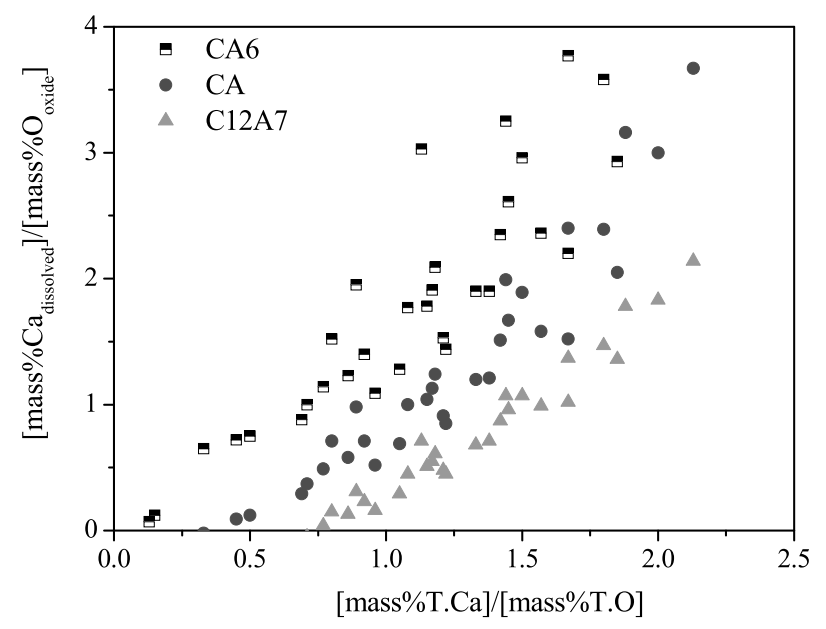

Fig. 3. The relationship between T.Ca/T.O and $\mathrm{Ca}_{\text {dissolved }} / \mathrm{O}_{\text {oxide }}$ with various calcium aluminates.
The relationship between T.Ca/T.O and $\mathrm{MgO}$ content in inclusions of all slab samples is shown in Fig. 4. It can be seen that $\mathrm{MgO}$ content in inclusions obviously decreases with the increase of T.Ca/T.O. In the case T.Ca/T.O is close to zero, $\mathrm{MgO}$ content in inclusions is $15-20 \%$. In the case T.Ca/T.O is over $1.5, \mathrm{MgO}$ content in inclusion is less $5 \%$, which indicates that $\mathrm{MgO}$ content in inclusions was reduced by $\mathrm{Ca}$ being fed into molten steel.

\subsection{Effect of T.Ca/T.O on $\mathrm{Al}_{2} \mathrm{O}_{3}$ Content of Inclusions}

In order to better control inclusions composition, the relationship between $\mathrm{Al}_{2} \mathrm{O}_{3}$ content in inclusions and T.Ca/T.O is given and shown in Fig. 5, where the spots with the shape of box and solid triange are reported by $\mathrm{M}$. Numata et l. $^{3,4)}$ and G. W. Yang et al. ${ }^{1,2)}$ respectively and their results is almost in accordance with the ones in present work in the case of T.Ca/T.O less than 1.5 and there exists a certain difference in the case of T.Ca/T.O over 1.5. Besides, it is divided into three parts including $\mathrm{A}, \mathrm{AC}$ and $\mathrm{CC}$ respectively, by dot line based on T.Ca/T.O in steel. It can be seen that $\mathrm{Al}_{2} \mathrm{O}_{3}$ content of inclusions almost linearly decreases with the increase of T.Ca/T.O in steel. In the case of T.Ca/T.O in steel over $1.5, \mathrm{Al}_{2} \mathrm{O}_{3}$ content in inclusions is very less, which means the type of inclusion is close to $\mathrm{CaO}-\mathrm{CaS}$ complex inclusion; In the case of T.Ca/T.O in

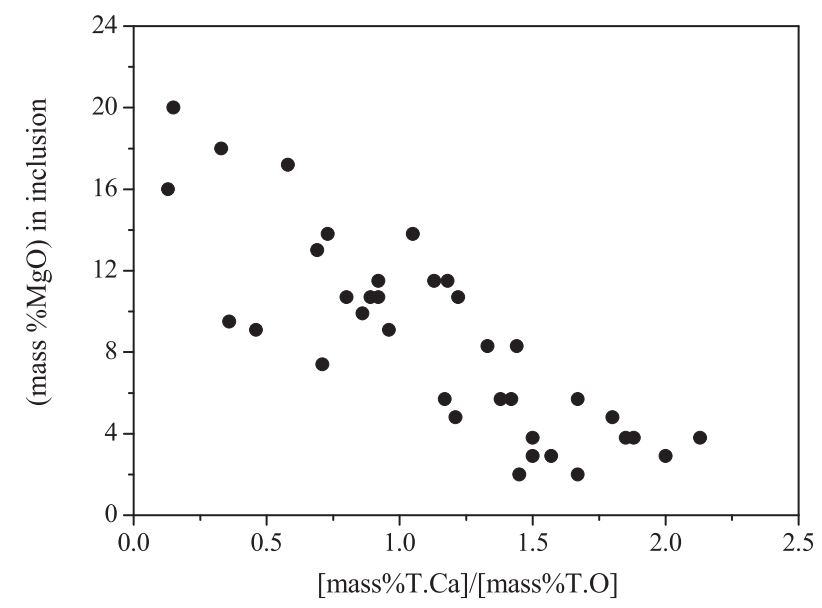

Fig. 4. The relationship between T.Ca/T.O and $\mathrm{MgO}$ content in inclusions of all slab samples.

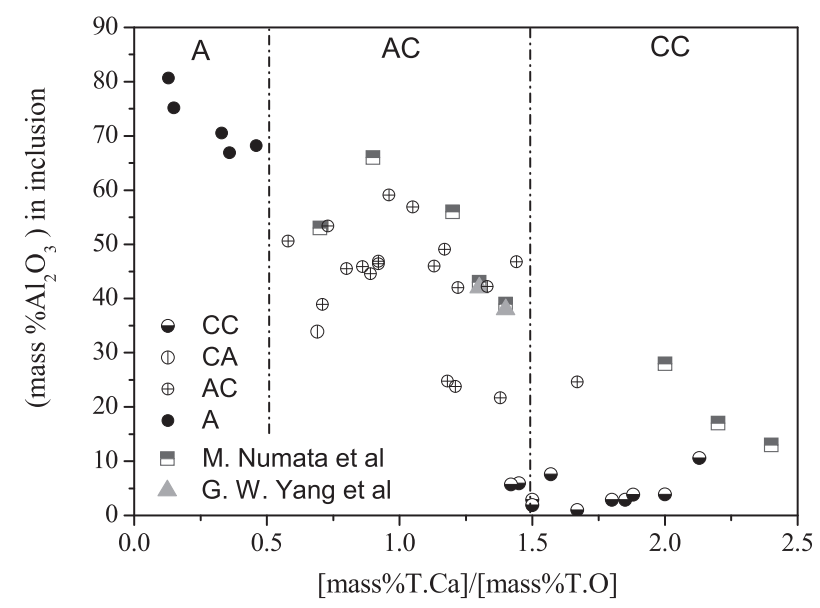

Fig. 5. The relationship between T.Ca/T.O and $\mathrm{Al}_{2} \mathrm{O}_{3}$ content in inclusion of all slab samples. 
steel less than $0.5, \mathrm{Al}_{2} \mathrm{O}_{3}$ content in inclusion is very high even close $90 \%$, which indicates the type of inclusion is $\mathrm{Al}_{2} \mathrm{O}_{3}$ inclusion or low modified calcium aluminates; In the case of T.Ca/T.O in steel greater than 0.5 and less than 1.5, the type of inclusion is $\mathrm{Al}_{2} \mathrm{O}_{3}-\mathrm{CaS}$ inclusion.

\subsection{Effect of T.Ca/S on the Modification Extent of $\mathrm{Al}_{2} \mathrm{O}_{3}$ Inclusions}

To clarify the effect of $\mathrm{S}$ content in molten steel on modification extent of $\mathrm{Al}_{2} \mathrm{O}_{3}$ inclusions by $\mathrm{Ca}$, the relation between T.Ca/S and modification extent of inclusions was studied and shown in Fig. 6, where the modification extent of inclusions was expressed by the mole ratio of $\mathrm{Ca}$ content from $\mathrm{CaO}$ and $\mathrm{CaS}$ in inclusions to $\mathrm{Al}$ content of $\mathrm{Al}_{2} \mathrm{O}_{3}$ in inclusions. It can be seen that the mole ratio of $\mathrm{Ca}$ to $\mathrm{Al}$ $((\operatorname{mole} \% \mathrm{Ca}) /(\operatorname{mole} \% \mathrm{Al}))$ in inclusion increases with the increase of $\mathrm{T} . \mathrm{Ca} / \mathrm{S}$ in steel, which means that increasing $\mathrm{T} . \mathrm{Ca} / \mathrm{S}$ in steel can significantly improve the modification extent of $\mathrm{Al}_{2} \mathrm{O}_{3}$ inclusions. If $\mathrm{Al}_{2} \mathrm{O}_{3}$ inclusions can be modified well into calcium aluminates, T.Ca/S in molten steel should be over 2.0, which means it is very difficult to modify alumina into well calcium aluminates in the case of more $\mathrm{S}$ content, which is accordance with the results of Ref. 5).

To understand the formation reason of $\mathrm{CaS}$ in complex inclusions, the relation between $(\mathrm{mole} \% \mathrm{Ca}) /(\mathrm{mole} \% \mathrm{Al})$ and CaS content of inclusions was studied and shown in Fig. 7. It is noticed that calcium of $\mathrm{CaS}$ in inclusions is contained in $(\mathrm{mole} \% \mathrm{Ca})$ and the reason can be explained as following: Firstly, $\mathrm{CaS}$ in $\mathrm{Al}_{2} \mathrm{O}_{3}-\mathrm{CaS}$ typed inclusions is mainly generated during casting solidification process and difficult to be formed in motel steel according to previous results of Ref. (8). Secondly, Calcium of CaS in inclusions has modified alumina into calcium aluminates in motel steel. So the ratio of $(\mathrm{mole} \% \mathrm{Ca})$ of $\mathrm{CaO}$ and $\mathrm{CaS}$ in inclusions to (mole $\% \mathrm{Al}$ ) in inclusions can better represent for the modification extent of calcium aluminates. It can be seen that $\mathrm{CaS}$ content in inclusions increases with $(\mathrm{mole} \% \mathrm{Ca}) /(\mathrm{mole} \% \mathrm{Al})$ of inclusions, which indicates that higher $(\mathrm{mole} \% \mathrm{Ca}) /(\mathrm{mole} \% \mathrm{Al})$ of inclusion makes $\mathrm{CaS}$ content more. From the above, it is can be inferred that, under the condition of the same $\mathrm{Ca}$ content for different slab samples, higher sulfur content in

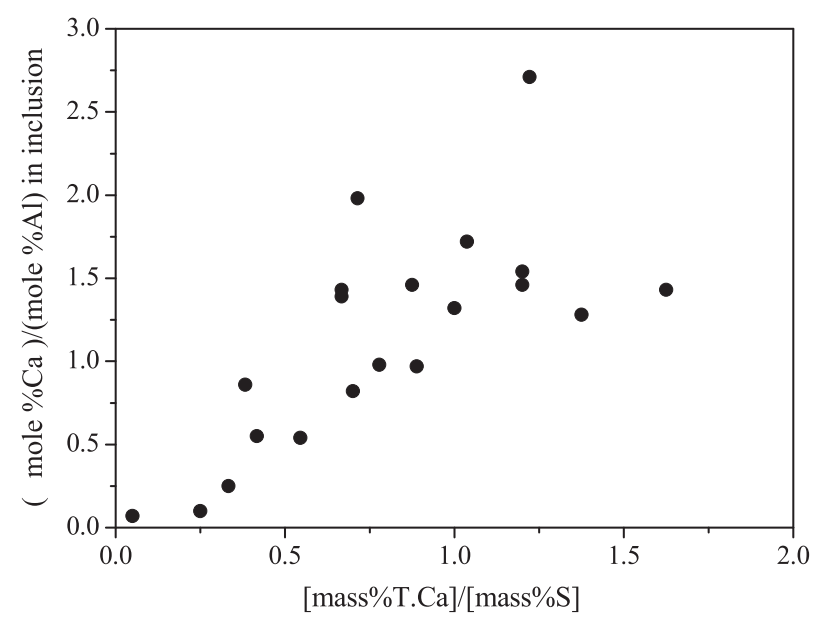

Fig. 6. The relationship between T.Ca/S and (mole $\% \mathrm{Ca}) /(\mathrm{mole} \% \mathrm{Al})$ in inclusion. steel suppresses the modification of $\mathrm{Al}_{2} \mathrm{O}_{3}$ inclusions by $\mathrm{Ca}$ and further makes less $\mathrm{S}$ content dissolve in complex inclusions and finally generates less $\mathrm{CaS}$ content in inclusions.

\subsection{Effect of T.Ca on the Cleanness of Steel}

In general, T.O content was considered as an important index to evaluate the cleanness of steel. The relationship between T.Ca and T.O is given in Fig. 8. It can be seen that T.O content doesn't change with T.Ca content in steel in the case of T.Ca less than $0.0018 \%$ and increases with T.Ca content in steel in the case of T.Ca over $0.0018 \%$. It can be inferred that excess calcium treatment results in reoxidation of steel and the reason can be explained as follow.

Firstly, the liquid steel was easier to exposed to atmosphere during calcium wires being fed into molten steel because of its good activity under high temperature and then reoxidation occurred. Secondly, lots of impurities were introduced by $\mathrm{Ca}$ wires, whose composition in the industrial trials is shown in Table 5, which could make steel cleanness worse. Finally, before calcium treatment, the equilibrium

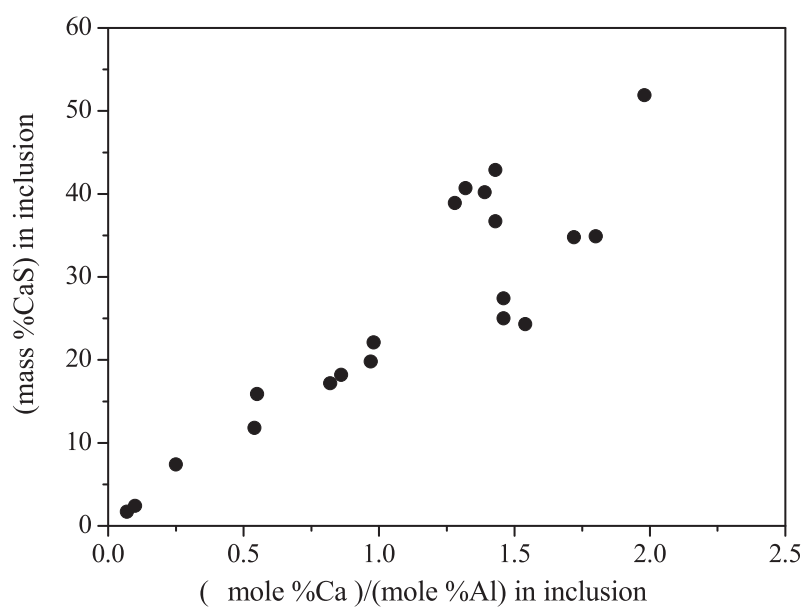

Fig. 7. The relationship between $\mathrm{CaS}$ content and (mole $\% \mathrm{Ca}) /$ (mole\% $\%$ l) in inclusion.

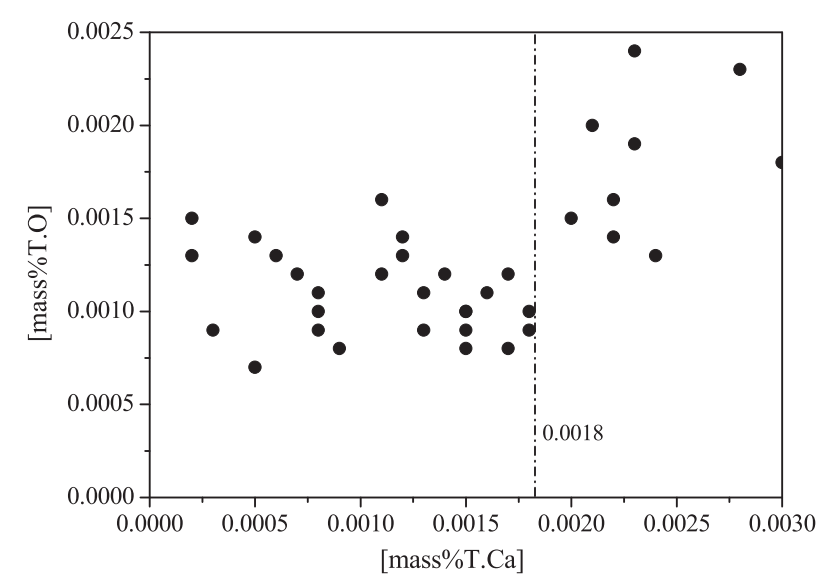

Fig. 8. The relationship between T.Ca and T.O content in inclusion.

Table 5. The composition of Ca wires in industrial trials.

\begin{tabular}{cccc}
\hline Wire type & Ca content mass $\%$ & Si content mass $\%$ & Other mass $\%$ \\
\hline Si-Ca wire & 28 & 52 & 20 \\
Ca wire & 96 & 0 & 4 \\
\hline
\end{tabular}


both dissolved aluminum and dissolved oxygen in molten steel can be described as Eq. (4). When amount of Ca wires was fed into molten steel, the Al-O equilibrium was broken and made chemical reaction continue toward the right side and generated more various calcium aluminates.

\subsection{Formation Mechanism of Various Typed Inclu- sions}

According to the above analysis, formation mechanisms of various typed inclusions are proposed.

\subsection{1. $\mathrm{Al}_{2} \mathrm{O}_{3}$ Based Inclusions}

For $\mathrm{Al}_{2} \mathrm{O}_{3}$ based inclusions, their formation mechanism could be described as following. At the end of LF refining, a small amount of $\mathrm{Mg}$ and $\mathrm{Ca}$ was generated in molten steel due to the feeding of $\mathrm{Al}$ alloy and reactions (8) and (9) took place, thus they reacted with existed $\mathrm{Al}_{2} \mathrm{O}_{3}$ inclusions to form $\mathrm{MgO}-\mathrm{Al}_{2} \mathrm{O}_{3}$ spinel and low modified calcium aluminates respectively expressed by reactions (10) and (11), which has been reported by researchers. ${ }^{9-12)}$

$$
\begin{gathered}
2[\mathrm{Al}]+3(\mathrm{CaO})_{\text {slag }}=\left(\mathrm{Al}_{2} \mathrm{O}_{3}\right)_{s}+3[\mathrm{Ca}] \ldots \ldots . . . . . \\
2[\mathrm{Al}]+3(\mathrm{MgO})_{\text {slag } / \text { fractary }}=\left(\mathrm{Al}_{2} \mathrm{O}_{3}\right)_{s}+3[\mathrm{Mg}] \ldots . . \\
\mathrm{x}[\mathrm{Mg}]+\frac{\mathrm{y}}{3}\left(\mathrm{Al}_{2} \mathrm{O}_{3}\right)_{s}=(\mathrm{MgO})_{x} \cdot\left(\mathrm{Al}_{2} \mathrm{O}_{3}\right)_{y-x}+\frac{2 \mathrm{x}}{3}[\mathrm{Al}] \ldots \\
\mathrm{x}[\mathrm{Ca}]+\frac{\mathrm{y}}{3}\left(\mathrm{Al}_{2} \mathrm{O}_{3}\right)_{s}=(\mathrm{CaO})_{x} \cdot\left(\mathrm{Al}_{2} \mathrm{O}_{3}\right)_{y-x}+\frac{2 \mathrm{x}}{3}[\mathrm{Al}] \ldots
\end{gathered}
$$

Meanwhile, only few or no Ca wires were fed into molten steel for heats with $\mathrm{Al}_{2} \mathrm{O}_{3}$ based inclusions, which made T.Ca content in molten steel was so less that reaction (11) was not sufficient. Moreover, the sulfur capacity of $\mathrm{Al}_{2} \mathrm{O}_{3}$ based inclusions is very less according to Ref. 8) based on $\mathrm{KTH}$ model, resulting that CaS was not easy to precipitate during solidification process.

\subsection{2. $\mathrm{Al}_{2} \mathrm{O}_{3}-\mathrm{CaS}$ Inclusions}

For samples with $\mathrm{Al}_{2} \mathrm{O}_{3}-\mathrm{CaS}$ inclusions in slab, a large amount of $\mathrm{Ca}$ wires were fed into molten steel, which makes T.Ca content was higher and then reactions (12) or (13) were taken place to generate better modified calcium aluminates based on the following reason: $\mathrm{MgO}$ content was decreased with the increase of T.Ca/T.O shown in Fig. 4, which indicates $\mathrm{MgO}$ in inclusions could be reduced by dissolved $\mathrm{Ca}$ to form $\mathrm{CaO}$. Meanwhile, excess calcium made reaction (14) occur towards the right side of forming better modified calcium aluminates. Because well modified calcium aluminates have more sulfur capacity, which makes $\mathrm{CaS}$ component precipitate during solidification process based on the theory of previous research results. ${ }^{8,10)}$

$$
\begin{aligned}
& \mathrm{x}[\mathrm{Ca}]+(\mathrm{MgO})_{y} \cdot\left(\mathrm{Al}_{2} \mathrm{O}_{3}\right)_{z} \\
= & (\mathrm{MgO})_{y-x} \cdot(\mathrm{CaO})_{x} \cdot\left(\mathrm{Al}_{2} \mathrm{O}_{3}\right)_{z}+x[\mathrm{Mg}] \\
\mathrm{x} & \mathrm{Ca}]+(\mathrm{MgO})_{y} \cdot\left(\mathrm{Al}_{2} \mathrm{O}_{3}\right)_{z} \cdot(\mathrm{CaO})_{m} \\
= & (\mathrm{MgO})_{y-x} \cdot(\mathrm{CaO})_{x+m} \cdot\left(\mathrm{Al}_{2} \mathrm{O}_{3}\right)_{z}+x[\mathrm{Mg}]
\end{aligned}
$$

$$
3[\mathrm{Ca}]+(\mathrm{CaO})_{x} \cdot\left(\mathrm{Al}_{2} \mathrm{O}_{3}\right)_{y}=(\mathrm{CaO})_{3+x} \cdot\left(\mathrm{Al}_{2} \mathrm{O}_{3}\right)_{y-1}+2[\mathrm{Al}]
$$

\subsection{3. $\mathrm{CaO}-\mathrm{CaS}$ Inclusions}

For samples with $\mathrm{CaO}-\mathrm{CaS}$ inclusions in slab, larger amount of $\mathrm{Ca}$ wires were fed into molten steel, which made reactions (12) and (13) continuously occured resulting in no or few $\mathrm{MgO}$ content being detected. Moreover, reaction (14) would proceed towards the right side and formed better modified calcium aluminates. With the increase of modification extent of calcium aluminates, sulfur capacity of inclusions increased and $\mathrm{Al}_{2} \mathrm{O}_{3}-\mathrm{CaS}$ inclusions would be formed if reaction (14) didn't proceed. However, for samples with $\mathrm{CaO}-\mathrm{CaS}$ inclusions in slab, $\mathrm{Ca}$ content of molten steel was excess, which made reaction (14) occurred continuously and $\mathrm{Al}_{2} \mathrm{O}_{3}$ component of calcium aluminates was reduced gradually by $\mathrm{Ca}$ until few even no $\mathrm{Al}_{2} \mathrm{O}_{3}$ content. Finally, lots of $\mathrm{CaO}-\mathrm{CaS}$ inclusions were generated.

\section{Conclusion}

Inclusions in slab samples with various T.Ca, T.O and S content were investigated in low carbon aluminum killed steel with low sulfur content based on industrial experiments and the relationship between steel and inclusions was studied by analyzing inclusions characteristic being detected by SEM-EDS. The following conclusions were obtained.

(1) T.Ca/T.O in steel could better replace dissolved $\mathrm{Ca}$ to evaluate the extent of modification of alumina inclusions by $\mathrm{Ca}$.

(2) Inclusions changed from $\mathrm{Al}_{2} \mathrm{O}_{3}$ based inclusions to $\mathrm{Al}_{2} \mathrm{O}_{3}-\mathrm{CaS}$ inclusions and finally to $\mathrm{CaO}-\mathrm{CaS}$ inclusions with the increase of T.Ca/T.O in steel for slab samples and $\mathrm{MgO}$ and $\mathrm{Al}_{2} \mathrm{O}_{3}$ content in inclusions almost linearly decreased with T.Ca/T.O in steel.

(3) Increasing T.Ca/S in steel could improve the modification extent of alumina by $\mathrm{Ca}$ further increased $\mathrm{CaS}$ content of inclusions for slab samples with $\mathrm{Al}_{2} \mathrm{O}_{3}-\mathrm{CaS}$ inclusions.

(4) The formation mechanism of inclusions including $\mathrm{Al}_{2} \mathrm{O}_{3}$ based inclusions, $\mathrm{Al}_{2} \mathrm{O}_{3}-\mathrm{CaS}$ inclusions and $\mathrm{CaO}-$ $\mathrm{CaS}$ inclusions was discussed.

\section{REFERENCES}

1) G. W. Yang, X. H. Wang, D. Yang and X. Hao: Metall. Mater. Trans. $B, 46 \mathrm{~B}(2015), 145$.

2) G. W. Yang and X. H. Wang: ISIJ Int., 55 (2015), 126.

3) M. Numata and Y. Higuchi: ISIJ Int., 52 (2012), 2013.

4) M. Numata, Y. Higuchi and S. Fukagawa: Tetsu-to-Hagané, 84 (1998), 159.

5) S. K. Choudhary and A. Ghosh: ISIJ Int., 48 (2008), 1552.

6) L. Holappa, M. Hämäläinen, M. Liukkonen, M. Lind and K. Tshilombo: Ironmaking Steelmaking, 30 (2003), 111.

7) H. Suito and R. Inoue: ISIJ Int., 36 (1996), 528.

8) D. W. Zhao, H. B. Li, C. L. Bao and J. Yang: ISIJ Int., 55 (2015), 2125 .

9) M. Jiang, X. H. Wang, B. Chen and W. J. Wang: ISIJ Int., 50 (2010), 95.

10) J. Guo, S. S. Cheng and Z. J. Cheng: ISIJ Int., 53 (2013), 2142.

11) W. Yang, L. F. Zhang, X. H. Wang, Y. Ren, X. F. Liu and Q. S. Shan: ISIJ Int., 53 (2013), 1401.

12) S. F. Yang, Q. Q. Wang, L. F. Zhang, J. S. Li and K. Peaslee: Metall. Mater. Trans. B, 43B (2012), 731. 